\title{
NOTES ON THE DISTRIBUTION OF INVASIVE FRESHWATER SNAIL POMACEA CANALICULATA (LAMARCK, 1822) AND P. INSULARUM ( D'ORBIGNY, 1835) IN INDONESIA
}

\author{
RISTIYANTI M. MARWOTO \& NUR R. ISNANINGSIH \\ Research Center for Biology, Gedung Widyasatwaloka, \\ Jalan Raya Jakarta - Bogor Km 46, Cibinong, BOGOR 16911
}

Received 24 November 2011/Accepted 10 December 2011

\begin{abstract}
The freshwater snails Pomacea canaliculata and P. insularum have been reported as important invasive species causing damage to crops and predominantly wetland rice in Asia. These snails are known as "Golden Apple Snail" (GAS), an introduced species from Argentina. Pomacea canaliculata or known as "keong mas, keong murbei" was introduced in Indonesia around 1983, and after more than 20 years, it now can be found very abundant at various habitats such as marshes, ponds, irrigations, lakes and rice fields in almost all places in Indonesia.

Based on the collections of these snails deposited in the MZB (Museum Zoologicum Bogoriense, Research Center for Biology) and secondary data (references), the distribution of these two snails was studied. Pomacea canaliculata is widely distributed, while P. insularum is only found at Lake Semayang and Lake Balikpapan in Kalimantan. The distribution map is presented and will be useful as a basic information to manage these invasive snails.
\end{abstract}

Key words: distribution, snail, invasive, Pomacea canaliculata, P. insularum, Indonesia

\section{INTRODUCTION}

The freshwater snails Pomacea canaliculata and P. insularum have been reported as important invasive species causing damage to crops and predominantly wetland rice in Asia. Reports on the serious damage to rice in Malaysia, Philippines, Japan, Vietnam and Indonesia have been published (Hyunh 2006; Cuong 2006; Adalla \& Magsino 2006; Wada 2006; Suharto et al. 2006; Yahaya et al. 2006). These snails are known as "Golden Apple Snail" (GAS), an introduced species from Argentina. Pomacea canaliculata or named as "keong mas, keong murbei" was introduced in Indonesia around 1983, and after more than 20 years, the snail has spread and became

$\overline{\text { *Corresponding author : rist001@lipi.go.id }}$ 
very abundant in various habitats such as marshes, ponds, irrigations, lakes and rice fields in almost all places in Indonesia. In 2004, the first author visited Lake Semayang, Lake Loa Kang and Lake Balikpapan in East Kalimantan and collected shells of Pomacea, and unexpectedly shells that have similar characters with P. insularum (D'orbigny 1835) were found which have not been recorded before. This finding added the number of invasive snails in Indonesia to two species. Hayes et al. (2008) did not list $P$. insularum from Indonesia but he reported that this snail is present in Singapore and Malaysia. Rawling (2007) already stated that this snail is distributed widely in Southeast Asia and assumed that it was introduced to Indonesia from Malaysia. The occurrence of P. paludosa in Indonesia also have been reported by Suharto et al. 2006; Isnaningsih \& Marwoto (2011), but based on our examination, the shells are similar to P. canaliculata as mentioned by Cowie $e t$ al. 2006 who also noted that $P$. paludosa has not been detected in Asia. Detailed study on the occurrence of P. paludosa in Indonesia is still needed.

Damage to ricefields in Indonesia caused by $P$. canaliculata have been reported in medias such as newsletters, radios, and televisions (see appendix). Presently, even the data on their distribution in Indonesia is largely a speculation. The public awareness about the danger of the GAS (Golden Apple Snails) in general is very limited. Identifying the freshwater snails found in rice fields or irrigations is also difficult for the farmers and the local people. Usually they only recognised the occurrence of P. canaliculata based on the color of the egg capsules which are pink or bright reddish. Preliminary study on the distribution of $P$. canaliculata and $P$. insularum is needed to evaluate the distribution of these two species. The aim of this study is to present a basic data on the distribution of P. canaliculata and P. insularum in Indonesia. The data would be necessary for future studies and also to manage the invasive snail becoming pest in rice and threatens some native snails.

\section{MATERIALS AND METHODS}

The author used about 500 specimens deposited in the MZB (Museum Zoologicum Bogoriense, Research Center for Biology) and secondary data from references dated from 2005 up to 2011. All information of the localities where the snails have been collected from 1990 to 2011 were recorded and marked on the distribution map. Yellow dots represent the localities based on references and red data for the localities based on MZB's specimens of P. canaliculata, while the occurrence of P. insularum was indicated by star.

\section{RESULTS AND DISCUSSION}

Pomacea canaliculata of MZB collection came from 90 localities in Indonesia, distributed from the northern Sumatra (Aceh, Bukit Kese, Bengkulu Sibaganding,Manggung Pariaman, Danau Kerinci, Jambi, Danau Ranau, Lampung, Sigarung-garung, Tanggamus, Lampung, Krakatau), Java (Bogor, Tasikmalaya, 
Cianjur, Sukabumi, Krawang, Depok, Bekasi, Rawapening, Tuban, Jogya), Bali (Lake Tamblingan, Lake Bratan), Sulawesi (Maros, Manrepo, Buton, Palu, Bone, Pangkep), Kalimantan (Tau Lumbis, Lake Semayang, Lake Balikpapan, Malinau), and Papua (Wamena, Biak). While P. insularum was only recorded from three locations i.e Lake Semayang, Lake Loa Kang and Lake Balikpapan in East Kalimantan. The distribution of P. canaliculata and P. insularum is presented on Figure 1.

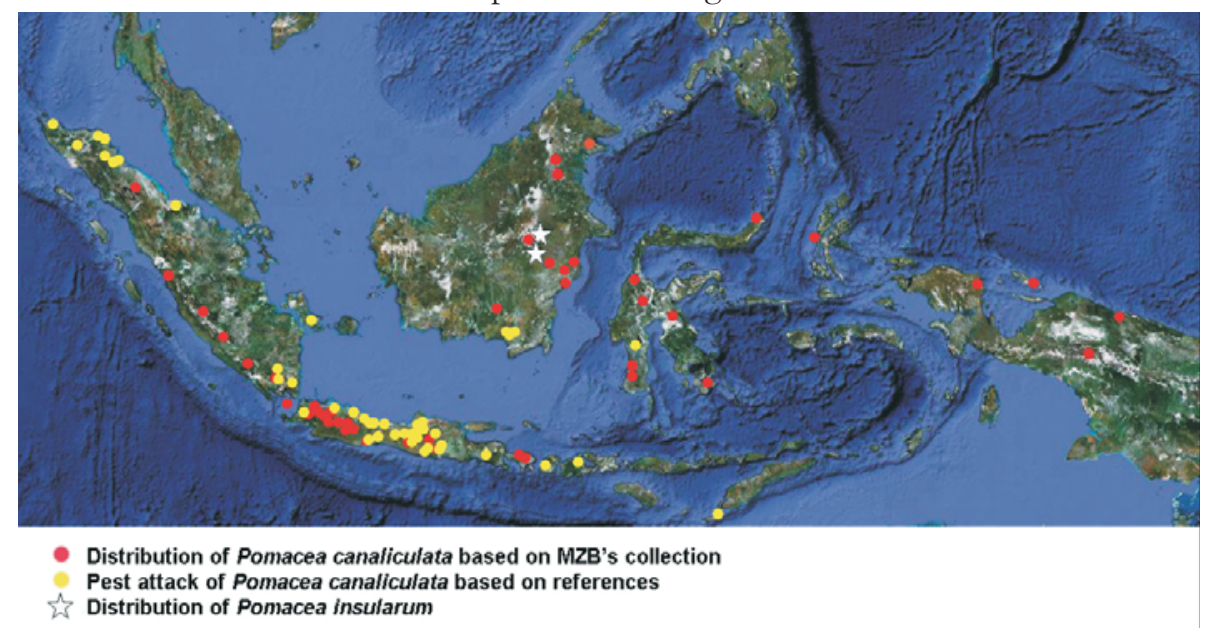

Figure 1: Map of the distribution of P. canaliculata and P. insularum in Indonesia

The distribution map (based on MZB collections \& secondary datas) shows that $P$. canaliculata is more widely distributed compared to that of $P$. insularum found only in Lake Loa Kang and Semayang in Balikpapan, Kalimantan. According to reports from newspapers and magazines the invasive snail $P$. canaliculata has damaged about 10 ha of ricefields in some places such as in Java, Sumatra, Sulawesi, Kalimantan, Sumbawa, Lombok or totally about more than 100 ha mainly in Aceh North Sumatra and some areas in Java. It seems that P. insularum possesses less physiological adaptability compared to $P$. canaliculata and need a specific habitat such as big lakes with muddy substrates and water hyacinth or water plantations like in Lake Loa Kang, Semayang and Balikpapan. Cazzaniga (2006:39) explained about the pattern of distribution and habitat of P. canaliculata in Argentina basically tropical and subtropical and fail to thrive in salty, very alkaline, poorly vegetated environments, with high risk of desiccation. Furthermore, he concluded that the fast expansion of this snail in Southeast Asia might be caused by some biological reasons but the main factor is human actions, since the snail has potential economic value. Pomacea canaliculata can be usually found in irrigated rice fields areas, or marshes and ponds. The populations will increase in rainy season and the juveniles or young snails will spread widely. The expansions of $P$. canaliculata in Indonesia are usually caused by human activities, especially in Jawa, Sumatra and Sulawesi where people have cultured the snail to be consumed (as edible snail) without realising the risk of the invasive snail (Isnaningsih \& Marwoto 2011). On the contrary, the local people in Balikpapan, East Kalimantan, generally prefer to consume freshwater fishes rather than snails. 


\section{Conchological}

The shell morphology description is based on general description to compare the two species, for detailed morphology and anatomy study see Cowie et al. 2006. The invasive snail $P$. canaliculata and P. insularum have similar shells. The shell differ mainly in having relatively higher spire and less broadly in $P$. canaliculata compared to that of P. insularum (Rawling et al. 2007), and the shell size of P. canaliculata is relatively smaller (Cowie et al.2006). The shell characters of both species are described as follows :.

\section{Pomacea canaliculata (Lamarck, 1822)}

Shell (Fig.2) globose, somewhat thin or transparent with smooth surface. Dextral coiling. Yellowish or dark brown, around the suture shell's color become pale. Sometimes there are dark spiral bands that become brighter at the body whorl. Spire high and pointed. Whorls 5.25 - 5.50, and rapidly increasing in size, the body whorl more globose. Umbilicus perforate. Suture curved to form deep channel. Apertural shape elongate cylindrical and the columellar lip not thickened.

Measurements: Height of shell 12.58 - $69.66 \mathrm{~mm}$; width of shell $4.94-64.90 \mathrm{~mm}$; height of body whorl $11.20-61.20 \mathrm{~mm}$; length of aperture $8.58-49.7 \mathrm{~mm}$; width of aperture $6.50-34.31 \mathrm{~mm}$.

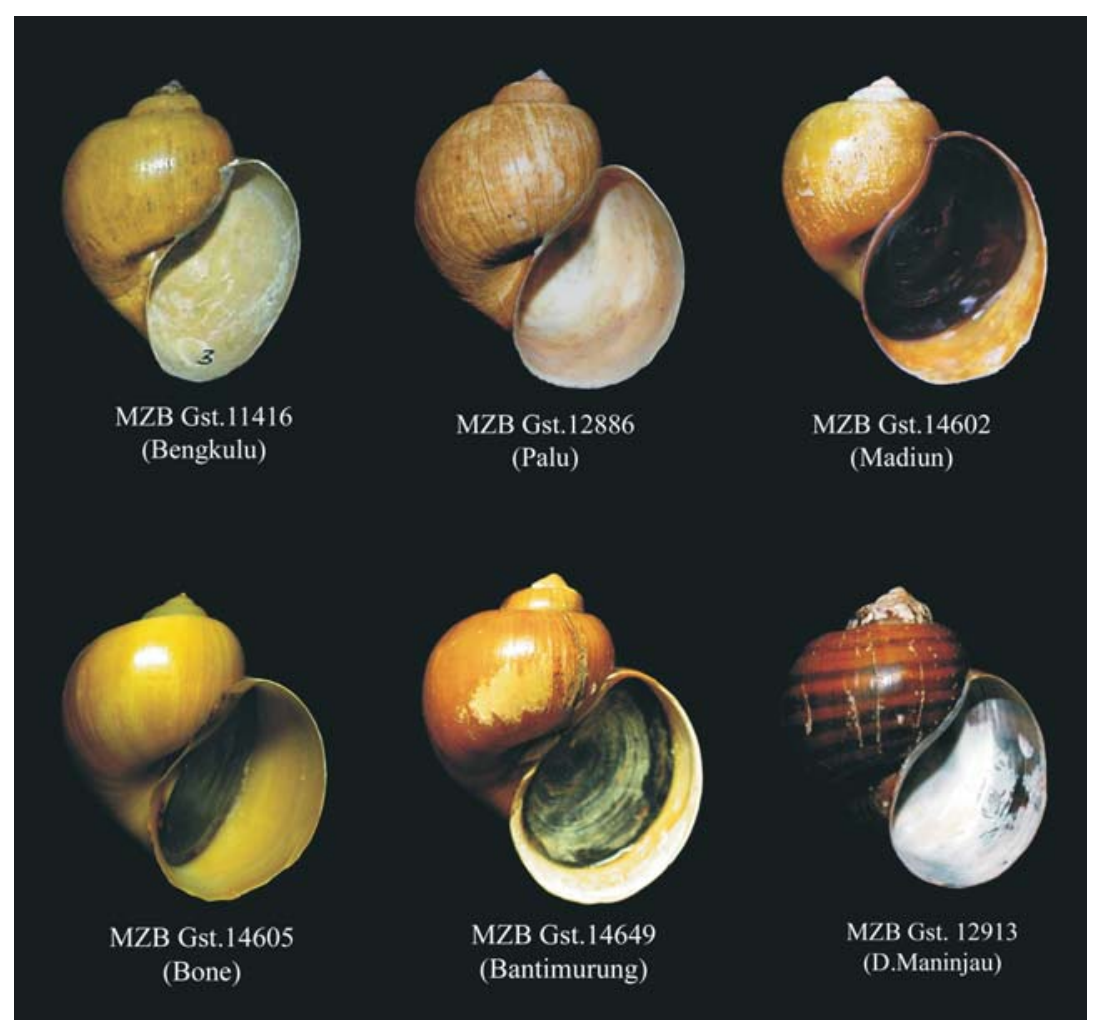

Fig. 2. Shell variation of Pomacea canaliculata from different localities. 


\section{Pomacea insularum (D'Orbiny, 1839)}

Shell (Figs.3) globose, somewhat thick compared to P. canaliculata. Dextral coiling. Brown and become darker near the umbilicus.Spire low and commonly erroded. Whorls 5, and rapidly increasing in size, the body whorl more globose. Umbilicus perforate. Suture with shallow channel. Apertural shape elongate cylindrical and the columellar lip not thickened.

Measurements: Height of shell 66.16-85.00 mm; width of shell $63.32-79.6 \mathrm{~mm}$; height of body whorl $64.60-77.55 \mathrm{~mm}$; length of aperture $46.05-59.25 \mathrm{~mm}$; width of aperture $33.24-44.45 \mathrm{~mm}$.
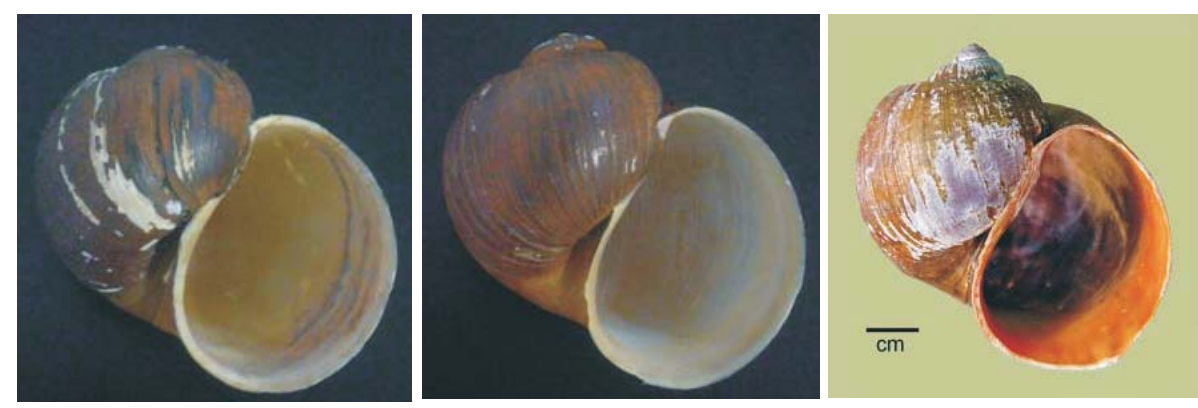

Figure 3. Shell variation of Pomacea insularum from Lake Loa Kang.

\section{ACKNOWLEDGEMENTS}

We would like to express our thanks to the anonymous reviewers who gave the comments and corrections on the first draft of this manuscript. This work was supported by DIPA of Research Center for Biology - LIPI (2009).

\section{REFERENCES}

Adalla CB, Magsino E. 2006. Understanding the golden apple snail (Pomacea canaliculata): Biology and early initiatives to control the pest in the Philippines. In: Global Advances in Ecology and Management of Golden Apple Snails. RC Joshi \& LS Sebastian (Eds), 199-213. Philrice. Philippines.

Cazzaniga NJ. 2006. Pomacea canaliculata : Harmless and Useless in Its Natural Realm (Argentina). In: Global Advances in Ecology and Management of Golden Apple Snails. RC Joshi and LS Sebastian (Eds), $37-$ 60. PhilRice. Philippines.

Cuong DN. 2006. The Golden Apple Snail in Vietnam. In Global Advances in Ecology and Management of Golden Apple Snails. RC Joshi and LS Sebastian (Eds), 243-254.

Cowie RH, Hayes KA, Thiengo SC. 2006. What Are Apple Snails? Confused Taxonomy and Some Preliminary Resolution. In: Global Advances in Ecology and Management of Golden Apple Snails. RC Joshi and LS Sebastian (Eds), 3-23. PhilRice. Philippines.

Hayes KA, Joshi RC, Thiengo SC, Cowie H. 2008. Out of South America: Multiple Origins of Non-native Apple Snails in Asia. Diversity and Distributions, 14 (4), 701-712. 
BIOTROPIA Vol. 18 No. 2, 2011

Huynh NK. 2006. Golden apple snails in Vietnam. In: Global Advances in Ecology and Management of Golden Apple Snails. RC Joshi and LS Sebastian (Eds), 255-266. PhilRice. Philippines.

Isnaningsih NR, Marwoto RM. 2011. Keong hama Pomacea di Indonesia: Karakter morfologi dan sebarannya (Molluska, Gastropoda, Ampullariidae). Berita Biologi, 10(4): 441-447.

Marwoto RM. 2006. Adaptasi Moluska Air Tawar di Danau Loa Kang dan Balikpapan Kalimantan Timur. Fauna Indonesia, 6 (2): 59-64.

Rawling TA, Hayes KA, Cowie RH, Collins TM. 2007. The Identity, Distribution, and Impacts of Non-native Apple Snails in the Continental United States. BMC Evolutionary Biology, 7: 1-14.

Suharto H, Marwoto RM, Heryanto, Mulyadi, Siwi SS. 2006. The Golden Apple Snail Pomacea spp. in Indonesia. In Global Advances in Ecology and Management of Golden Apple Snails. RC Joshi and LS Sebastian (Eds), 231-242. PhilRice, Philippines.

Wada T. 2006. Impact and control of introduced apple snail, Pomacea canaliculata (Lamarck), in Japan. In: Global Advances in Ecology and Management of Golden Apple Snails. RC Joshi and LS Sebastian (Eds), 181195. PhilRice. Philippines.

Yahaya H, Nordin M, Muhamad Hisham MN, Sivapragasam A. 2006. Golden Apple snails in Malaysia. In: Global Advances in Ecology and Management of Golden Apple Snails. RC Joshi and LS Sebastian (Eds), 215230. PhilRice. Philippines. 